FESIDE

Fundación Emilio Soldevilla de la Economía de la Empresa

\section{Management Letters / Cuadernos de Gestión}

journal homepage: http://www.ehu.eus/cuadernosdegestion/revista/es/

ISSN: 1131-6837 / e-ISSN: 1988-2157

\title{
Entrepreneurial intention a bibliometric approach
}

\section{Intención empresarial: un enfoque bibliométrico}

\author{
Víctor G. Alfaro-García ${ }^{a}$, Fabio Blanco-Mesa ${ }^{b}$, Ernesto León Castro* \\ a Universidad Michoacana de San Nicolás de Hidalgo (México). Calle de Santiago Tapia 403, Centro, 58000 Morelia, Michoacan, México - victor.alfaro@umich.mx - \\ https://orcid.org/0000-0002-0412-2166 \\ b Universidad Pedagógica y Tecnológica de Colombia. Avenida Central del Norte 39-115, 150003 Tunja, Tunja, Boyacá, Colombia - fabio.blanco01@uptc.edu.co - \\ https://orcid.org/0000-0002-9462-6498
}

* Corresponding author: Universidad Católica de la Santísima Concepción. Chile - eleon@ucsc.cl-https://orcid.org/0000-0002-0087-2226

\section{A R T I C L E I N F O}

Received 30 June 2021, Accepted 07 December 2021

Available online 4 March 2022

DOI: $10.5295 / \mathrm{cdg} .211558 \mathrm{el}$

JEL: L26, L29, L39

\begin{abstract}
A B S T R A C T
This paper aims to present a bibliometric analysis of the literature on an entrepreneurial intention that considers different topics to enhance starting a business. Using the Core collection of the Web of Science, 1,549 papers are found from 1900 to December 2020 to be analyzed. The analysis is focused on documents, authors, journals, countries, and keywords to detect areas and trends in this field of study. Likewise, bibliographic couplings, co-citation, and co-occurrences are analyzed. Findings show that the field has started to grow since 2010; the most influential authors and universities are in Spain and Taiwan, such as the case of Liñan, Liang, Ip, and Moriano.
\end{abstract}

Keywords: Bibliometric Analysis, Entrepreneurial Intention, Entrepreneurship, Co-Citation.

R E S U M E N

El objetivo principal de este trabajo es presentar un análisis bibliométrico de la literatura sobre la intención emprendedora que considere diferentes temas relacionados con la mejora de la puesta en marcha de negocios. Utilizando la colección Core de la Web of Science se encuentran un total de 1.549 artículos desde 1900 hasta diciembre de 2020 para ser analizados. El análisis se centra en documentos, autores, revistas, países y palabras clave para detectar áreas y tendencias en este campo de estudio. Asimismo, se analizan los acoplamientos bibliográficos, la co-citación y las co-ocurrencias. Los resultados muestran que el campo comienza a crecer desde 2010, que los autores y universidades más importantes están en España y Taiwán, tal es el caso de Linan, Liang, Ip y Moriano.

Palabras clave: Análisis Bibliométrico, Intención Emprendedora, Emprendimiento, Co-Cita. 


\section{INTRODUCTION}

Research related to entrepreneurial intention (EI) has been of great interest to the academic community (Liñán \& Fayolle, 2015). The beginnings of EI research can be traced back to the entrepreneurial event (Shapero, 1984) and planned behavior theory (Ajzen, 1991). Another important element for EI is the existence of Entrepreneurial Opportunities (Shane \& Venkataraman, 2000), which is considered the first element that must be presented to have entrepreneurship. With its discovery begins the decision to exploit such an idea. These approaches made it possible to explain entrepreneurship as an intention within a planned behavior (Krueger et al., 2000).

The EI is a complex phenomenon that has been studied from different individual and contextual determinants. For example, Shane (2003) indicates that the probability of taking advantage of an entrepreneurial opportunity is based on various psychological and non-psychological. Also, Ajzen (1991) provides an analysis that the intention is based on the attitude toward the behavior, subjective norms, and perceived behavioral control in his planned behavior theory. Finally, Institutional theory has proven to be helpful to understand EI (Bruton et al., 2010; Phillips \& Tracey, 2016). Institutional theory is related to how people and organizations behave based on regulatory structures, governments, social and cultural pressures, and laws (DiMaggio, 1988). In this sense, the study of EI has had diverse inclinations focused on the intention model, education, gender, culture, and so on (Liñán \& Fayolle, 2015).

The intention model highlights cultural values and society's perception of entrepreneurship (Liñán \& Chen, 2009), effects of perceived learning from entrepreneurship-related courses, and entrepreneurial self-efficacy (Zhao et al., 2005). In education is focused on enterprise education (Fayolle \& Gailly, 2015; Peterman \& Kennedy, 2003), university students predicting models (Farhangmehr et al., 2016; López-Núñez et al., 2021), cross-cultural beliefs and intentions (Tremblay \& Gasse, 2011), Personalities traits (Cai et al., 2021) and so on. In gender has taken into account aspects as socially constructed gender stereotypes in entrepreneurship and their influence on men and women's entrepreneurial intentions (Gupta et al., 2009), gender effects on entrepreneurial self-efficacy (Wilson et al., 2007), entrepreneurial attributes (Díaz-García \& Jiménez-Moreno, 2010), gender and culture influence in entrepreneurial perceptions (Shinnar et al., 2012).

This breadth of perspectives has made EI a diverse and multidisciplinary field with business, education, and psychological approaches, which have been adopting other issues related to sustainability, emerging economies, digitalization, family businesses, and the use of fuzzy systems. Given this importance, several review studies have been carried out with different methodological approaches, using their methods, techniques, and data.

One of the most notable reviews is Zhao et al. (2010), who conducted a meta-analytic review relating entrepreneurial personality and intention to entrepreneurial performance. Findings highlight five personality dimensions: conscientiousness, openness to experience, emotional stability, extraversion, and agreeableness, where five of them are related to both entrepre- neurial intentions and entrepreneurial performance. Thus, this study shows that personality constructs have a role to play in understanding entrepreneurial processes and the variables that attract people (Zhao et al., 2010). Likewise, Bae et al. (2014) presents a meta-analytic review, which is focused on entrepreneurship education and entrepreneurial intention. They used several databases, selected management and entrepreneurship journals, conference proceedings, unpublished papers, and working papers and key articles. Findings show a positive relationship between entrepreneurship education and entrepreneurial intention, where cultural dimensions played a significantly positive role in the entrepreneurship education-entrepreneurial intentions relationship (Bae et al., 2014). Based on these results, it is recommended to identify other criteria to assess the effects of entrepreneurship education, such as knowledge, entrepreneurial skills, actual behavior, or performance as better constructs than entrepreneurial intentions (Bae et al., 2014).

Other reviews have focused on bibliometric studies, which provide helpful indicators that show relevant aspects of topics using cited and thematic analytics. In this sense, Liñán and Fayolle (2015) present a literature review on entrepreneurial intentions, where was analyzed 409 papers addressing entrepreneurial intention between 2004 and 2013. This study carried out citation analysis of recent research to categorize the main areas of specialization (core entrepreneurial, intention model personal-level variables, entrepreneurship education, context, and institutions entrepreneurial process) and thematic analysis to identify the specific themes within each category. Thus, these works show evidence of the evolution of the EI focused on providing a precise categorization to focus EI studies for students, researchers, and practitioners. Although it presents exciting results, one of its main limitations lies in the methodology, as it is susceptible to not considering all articles or publications. Along the same lines, Ruiz-Alba et al. (2020) presented a bibliometric analysis to identify the main authors and influential universities on EI. This study used the Scopus database selected 377 articles from 01/01/1993 to 08/07/2016 (more or less 24 years of research). In addition, this sample has conducted a mapping, clustering, and rankings of journals, universities, and top authors. Finally, this study tries to show research streams and gaps to clarify the state of the research. The main limitations in methodology are in the keywords and time that were used in the search.

Therefore, these reviews have been developed from different perspectives and using different methodologies that present different advantages and limitations to cover such a broad topic as entrepreneurial intention. Thus, by looking at the potential for topics not covered or not widely developed and considering the largest number of articles and covering a wider time gap, we seek to offer a complete scope on the subject and its evolution.

Under this motivation, the main aim of this paper is to present a bibliometric approach of the literature on the entrepreneurial intention that considers different topics related to enhancing start business. The methodology uses the WoS core collection dataset to obtain the EI-related data using a Boolean equation. Thus, 1549 papers were found from 1996 to December 2020 
and analyzed impact, productivity, performance, and similarity. They are focused on documents, authors, journals, countries, and keywords to detect areas and trends in this field of study. Likewise, co-citations, bibliographic couplings, co-occurrences, and co-authorships are analyzed. Findings show that the field has started to grow since 2010; the most influential authors and universities are in Spain and Taiwan, such as the case of Liñan, Liang, Ip, and Moriano.

The present study is structured as follows: Section 2 presents the methodology used to develop the bibliometric study, examining the bibliometric methods and software used, their purpose, and explaining the search methodology used to obtain the database investigated. Section 3 presents the main generalities, articles, authors, countries, journals, universities, and keywords. Finally, section 4 presents the discussion of the work, and section 5 the conclusions detecting potential future research.

\section{BIBLIOMETRIC METHOD}

Bibliometrics is a science based on quantitive analysis of articles published in a specific area (Blanco-Mesa et al., 2017; Gaviria-Marín, 2021; Romero et al., 2021). The bibliometric analysis allows an analysis to be made of the impact or influence of scientific publications in quality or performance through bibliometric indicators (Moed, 2009). Likewise, bibliometric studies started in library and information science, expanded to all research areas to become very important in different fields (Bar-Ilan, 2008). According to Blanco-Mesa (2019), these studies allow observing a complete analysis on a specific topic offering a guide for researchers to find new spaces within a field and make novel contributions. Thus, the main purpose is to provide useful indicators that show relevant aspects of topics, authors, research, journals, etc. In this sense, this study is focused on EI studies to show a complete overview of this field.

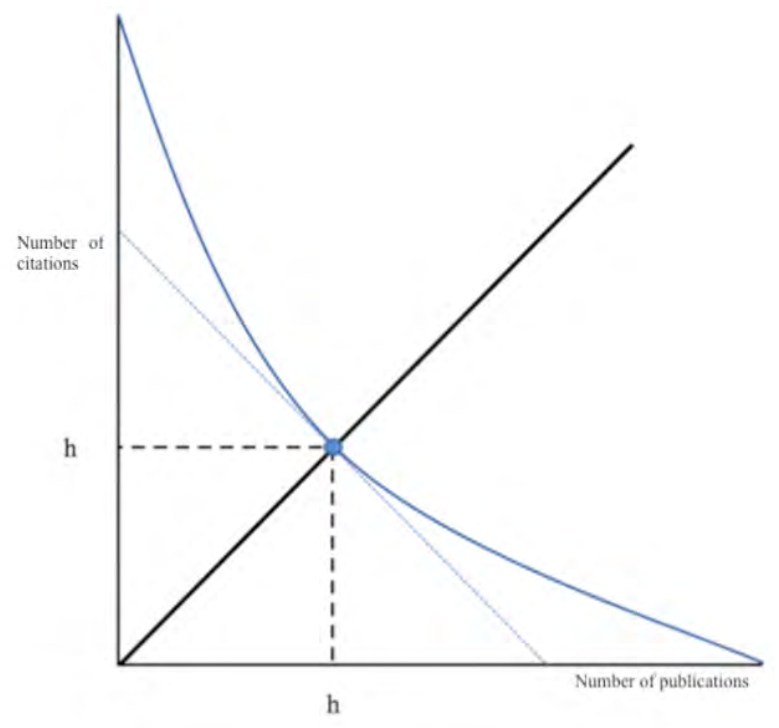

Figure 1

Graphical representation of the $\mathrm{H}$-index

Source: Taken from Hirsch (2005).
This study considers indicators of impact (Impact Factor), productivity, and performance (H-index). The impact factor is observed in the journals that publish the articles (Garfield, 1972), productivity is focused on the amount of published research and the $\mathrm{H}$ index (Hirsch, 2005) as an indicator of the performance of the researcher (Alonso et al., 2009), countries (Guan \& Gao, 2008), universities (Schubert, 2007) and journals (Braun et al., 2006). The H-index characterizes the scientific output based on the number of published articles and the number of citations these papers have achieved (Hirsch, 2005) (see Figure 1).

A similarity approach analysis is also carried out using the VOSviewer software to establish similarities (Merigó et al., 2017) such as citation, co-citation, bibliographic coupling, co-authorship, and co-occurrence keywords which are represented in cluster diagrams differentiated by a color scale. For this study, the following limits are established for each of the analyses; Co-occurrence: limit 20 all keywords and10 authors; Citation: documents limit 100; journal limit 10; universities five documents and five citations; Bibliographic coupling: 50 citations, journals 20 documents and five authors; Co-citation: number of citations of a cited reference 100 .

The Core Collection of the Web of Science (WoS) is considered to select the data to be analyzed. The following words entrepreneurial, entrepreneur and intention, are considered to establish the search equation for the information. Therefore, the search query is as follows, for keywords in the topic, i.e., title, abstract, keywords, and keywords plus, search for "Entrepreneurial intention ${ }^{\star}$ " OR "Entrepreneur* AND intention*". To increase the replicability of the study (Liu, 2019), please observe that the database used for the search process includes the next citation indexes: Science Citation Index Expanded (1900-present), Social Sciences Citation Index (1900-present), Arts \& Humanities Citation Index (1975-present), Conference Proceedings Citation Index-Science (1990-present), Conference Proceedings Citation Index- Social Science \& Humanities (1990-present), Book Citation Index- Science (2005-present), Book Citation Index- Social Sciences \& Humanities (2005-present), and Emerging Sources Citation Index (2015-present).

Although related topics such as motivation, personality, and behavior exist within the topic studied, they are not considered elements used to explain the intention considering that they are contained in it. Nevertheless, a search was done with these words, and the results had two effects. First, there were many articles not related to EI but closer to psychological issues. Secondly, there is an influx of papers related to entrepreneurship that are not related to intention. In this sense, it is observed that these terms are widely used to explain other topics that are not related to the subject under study. Finally, the study considers the period from 1900 to December 2020, the WoS categories, and all types of documents. The result is a total of 1,549 documents related to EI.

\section{RESULTS}

This section then presents the results of the analysis of the data collected. These results are divided into the following sections: General, evolution, and citation structure, the TOP-15 
most cited papers, the TOP-15 most-cited authors, the leading countries in the field, the most relevant journals in EI, leading universities, and keyword analysis.

\subsection{Evolution and citation structure}

Figure 2 shows the evolution of the academic field in entrepreneurship intention. As it can be seen, there has been an ex- ponentially increasing productivity and interest in the research field. It is interesting to note that since the first paper in 1991, the productivity in this area of knowledge has been moderate. In the earlies 2010s, the topic started receiving much attention, and the productivity of papers raised. However, it is also interesting to observe that in 2018 the productivity decreased, even compared to the previous year. 2019 and 2020 show increased volumes of both papers and citations.

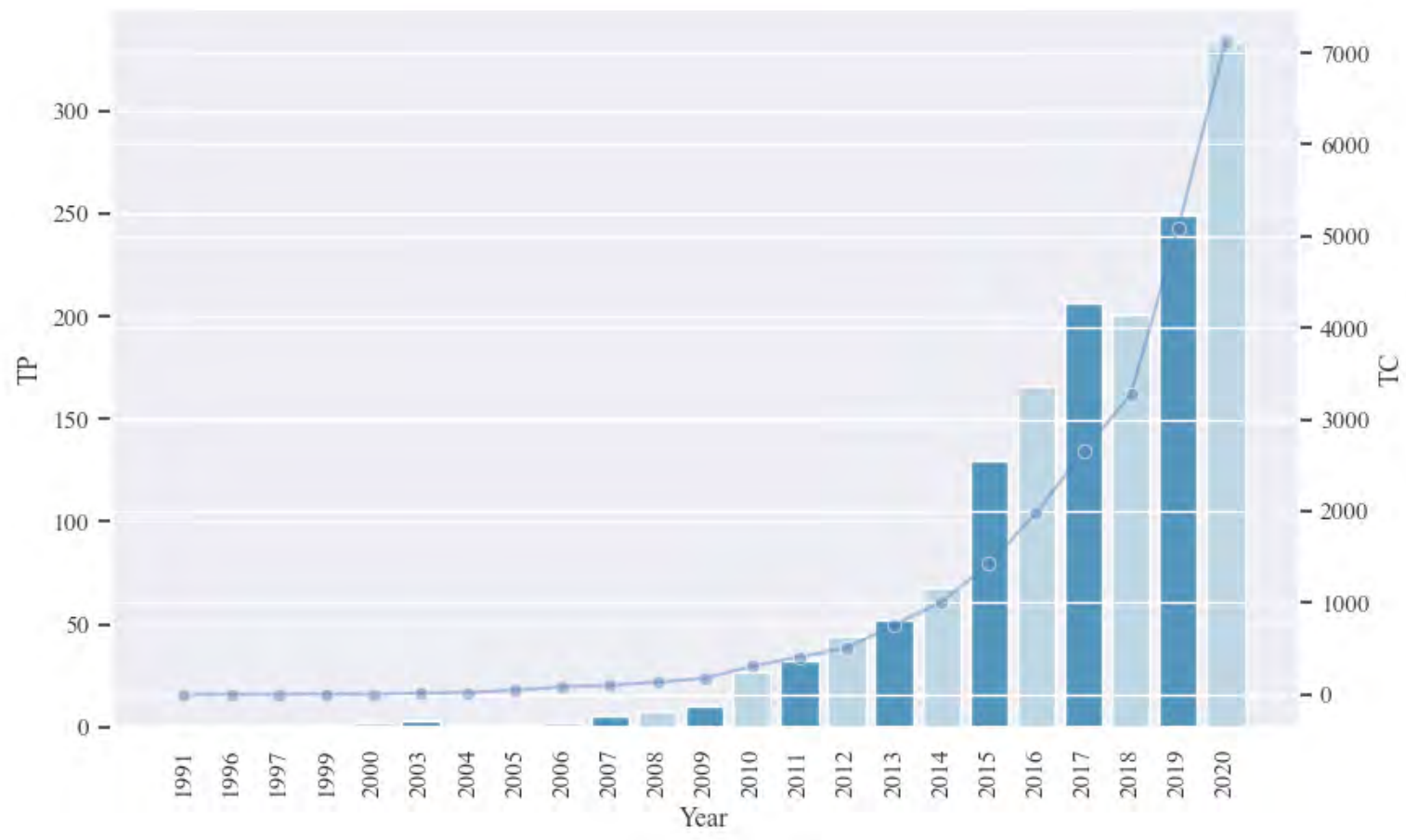

Figure 2

Entrepreneurial intention evolution

Source: Elaboration based on WoS.

Table 1

Citation structure of entrepreneurial intention academic field

\begin{tabular}{lcc}
\hline \multicolumn{1}{c}{ Cited references } & Total Publications & $\%$ \\
\hline$\geq 1000$ citations & 2 & 0.2 \\
$\geq 600$ citations & 4 & 0.3 \\
$\geq 300$ citations & 9 & 0.7 \\
$\geq 100$ citations & 40 & 3.4 \\
$\geq 50$ citations & 46 & 3.8 \\
$\geq 10$ citations & 314 & 25.1 \\
$<10$ citations & 1,134 & 66.5 \\
\hline Total & 1,549 & 100.0
\end{tabular}

Source: Elaboration based on WoS.

Table 1 shows the general citation structure of EI. Here, it can be observed that 55 documents have reached over 100 citations; this represents $4.5 \%$ of the papers. In specific 2 of the papers reach more than 1,000 citations, four reach more than 600 citations, and 9 surpass 300 citations. Please see Table 2 for a detailed analysis of the most cited papers.

This characteristic citation structure relates to the field's novelty, which can also be connected to Figure 2, as the increased field production starts around 2014.

This graph shows four relevant nodes where the works of Ajzen (1991), Shapero (1984), Krueger et al. (2000), and Liñán and Chen (2009) stand out. Studies have been based on the theory of planned behavior (Ajzen, 1991) and the entrepreneurial event (Shapero, 1984) as models to determine the existence of behaviors oriented towards entrepreneurial activities. From these, we study the intentional behaviors to start an entrepreneurial venture (Krueger et al., 2000) from different approaches, methods, subjects of study, and approaches (Liñán \& Chen, 2009). Thus, research on entrepreneurial intention has focused on the behavior of people who start an entrepreneurial activity, seeking to explain why people undertake, what shapes that behavior, and what motivates them. 


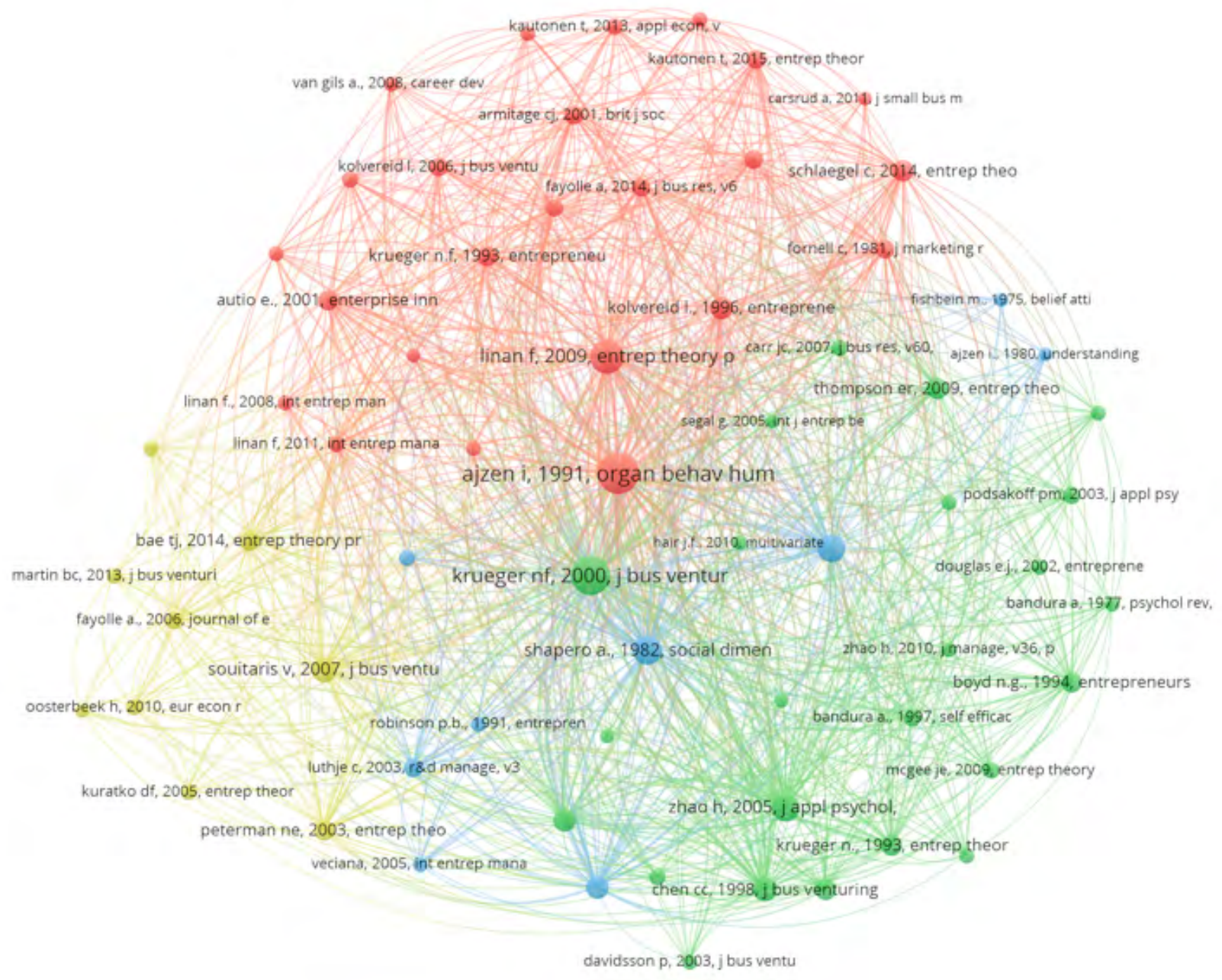

Figure 2

Co-Citation references

Source: Own elaboration based on WoS using VOSviewer

(Co-citation number of citations of a cited reference 100).

\subsection{Papers}

In this section, an analysis of the top 15 cited documents is performed. In general, from the 1,549 papers included in this study, the top 15 most cited papers sum 9,474 citations. These papers are considered the most influential documents in EI and serve as the foundation for the newest approaches in this area of knowledge.

Krueger et al. (2000) published the most cited paper of this study. In Competing models of entrepreneurial intentions, the authors compare two intention-based models for predicting EI using regression analyses; this paper finds that the promotion of EIs is "thoroughly feasible." Zhao et al. (2005) publish the mediating role of self-efficacy in the development of entrepreneurial intentions, where propose a structural equation model to assess the role that self-efficacy has on the EI of students in 5 different universities. The results show that a series of factors on EIs "were fully mediated by entrepreneurial self-efficacy." Finally,
Liñán and Chen (2009) propose a structural equation modeling technique to assess Ajzen's theory of planned behavior-based questionnaire on 519 individuals to explore EI. Results show a series of findings around EI, with special emphasis on the role of cultural values.

In Figure 3, one can see the relationships of the bibliographically coupled works, which helps you know how the research has been oriented towards common subjects. This process is called bibliographic coupling and shows the probability that a paper is cited by at least two papers (Weinberg, 1974). In this case, the purple nodes represent the oldest papers and the yellow ones the most recent ones. It should be noted that the larger nodes have more bibliographic links to other works. This is evidence that the work on EI has been directed towards the study of entrepreneurship education (Bae et al., 2014; Peterman \& Kennedy, 2003; Souitaris et al., 2007), behavioral factors of entrepreneurship (Kautonen et al., 2011; Krueger et al., 2000; Schlaegel \& Koenig, 2014; Zhao et al., 2005), aspects related to culture and gender 
(Liñán \& Chen, 2009; Shinnar et al., 2012; Wilson et al., 2007), and review analysis of the field (Fayolle \& Liñán, 2014; Liñán \&
Fayolle, 2015; Zhao et al., 2010). Thus, the lines have been developed in various contexts and approaches.

Table 2

Most influential papers in entrepreneurial intention

\begin{tabular}{|c|c|c|c|c|c|c|}
\hline $\mathbf{R}$ & AT & A & $\mathbf{J}$ & TCWC & PY & TC/PY \\
\hline 1 & $\begin{array}{l}\text { Competing models of entrepreneurial } \\
\text { intentions }\end{array}$ & Krueger NF; Reilly MD; Carsrud AL & JBVE & 1,849 & 2000 & 92 \\
\hline 2 & $\begin{array}{l}\text { The mediating role of self-efficacy in the } \\
\text { development of entrepreneurial intentions }\end{array}$ & Zhao H; Seibert SE; Hills GE & JAPS & 1,031 & 2005 & 69 \\
\hline 3 & $\begin{array}{l}\text { Development and cross-cultural application of a } \\
\text { specific instrument to measure entrepreneurial } \\
\text { intentions }\end{array}$ & Linan F; Chen Yi-Wen & ETPR & 947 & 2009 & 86 \\
\hline 4 & $\begin{array}{l}\text { Do entrepreneurship programmes raise } \\
\text { entrepreneurial intention of science and } \\
\text { engineering students? the effect of learning, } \\
\text { inspiration, and resources }\end{array}$ & Souitaris V; Zerbinati S; Al-Laham A & JBVE & 823 & 2007 & 63 \\
\hline 5 & $\begin{array}{l}\text { Gender, entrepreneurial self-efficacy, and } \\
\text { entrepreneurial career intentions: implications } \\
\text { for entrepreneurship education }\end{array}$ & Wilson F; Kickul J; Marlino D & ETPR & 724 & 2007 & 56 \\
\hline 6 & $\begin{array}{l}\text { Enterprise education: influencing students' } \\
\text { perceptions of entrepreneurship }\end{array}$ & Peterman NE; Kennedy J & ETPR & 682 & 2003 & 40 \\
\hline 7 & $\begin{array}{l}\text { The relationship of personality to } \\
\text { entrepreneurial intentions and performance: a } \\
\text { meta-analytic review }\end{array}$ & Zhao H; Seibert SE.; Lumpkin GT & JOMA & 526 & 2010 & 53 \\
\hline 8 & $\begin{array}{l}\text { The relationship between entrepreneurship } \\
\text { education and entrepreneurial intentions: a } \\
\text { meta-analytic review }\end{array}$ & Bae TJ; Qian S; Miao C; Fiet JO. & ETPR & 454 & 2014 & 76 \\
\hline 9 & $\begin{array}{l}\text { The role of gender stereotypes in perceptions } \\
\text { of entrepreneurs and intentions to become an } \\
\text { entrepreneur }\end{array}$ & Gupta VK.; Turban DB.; Wasti SA; Sikdar A & ETPR & 380 & 2009 & 35 \\
\hline 10 & $\begin{array}{l}\text { Determinants of entrepreneurial intent: a meta- } \\
\text { analytic test and integration of competing models }\end{array}$ & Schlaegel C; Koenig M & ETPR & 371 & 2014 & 62 \\
\hline 11 & $\begin{array}{l}\text { Robustness of the theory of planned behavior in } \\
\text { predicting entrepreneurial intentions and actions }\end{array}$ & Kautonen T; van Gelderen M; Fink M & ETPR & 368 & 2015 & 74 \\
\hline 12 & $\begin{array}{l}\text { The proactive personality scale as a predictor of } \\
\text { entrepreneurial intentions }\end{array}$ & Crant JM & JSBM & 362 & 1996 & 15 \\
\hline 13 & $\begin{array}{l}\text { A systematic literature review on } \\
\text { entrepreneurial intentions: citation, thematic } \\
\text { analyses, and research agenda }\end{array}$ & Linan F; Fayolle A & IEMJ & 338 & 2015 & 68 \\
\hline 14 & $\begin{array}{l}\text { The future of research on entrepreneurial } \\
\text { intentions }\end{array}$ & Fayolle A; Linan F & JBRE & 317 & 2014 & 53 \\
\hline \multirow[t]{2}{*}{15} & $\begin{array}{l}\text { Entrepreneurial perceptions and intentions: the } \\
\text { role of gender and culture }\end{array}$ & Shinnar RS.; Giacomin O; Janssen F & ETPR & 302 & 2012 & 38 \\
\hline & Total & & & 9,747 & & \\
\hline
\end{tabular}

Source: Elaboration based on WoS.

Note: R: Ranking; AT: Article Title; A: Authors; J: Journal; TC: Times Cited; PY, Published Year; TC/PY, Times cited per year (considering PY minus the basis year 2020); JBVE: Journal of Business Venturing; JAPS: Journal of Applied Psychology; ETPR: Entrepreneurship Theory and Practice; JBVE: Journal of Business Venturing; JOMA: Journal of Management; JSBM: Journal of Small Business Management; IEMJ: International Entrepreneurship and Management Journal; JBRE: Journal of Business Research. Total is calculated as the sum of TCWC for the top 15 most cited IE papers. 


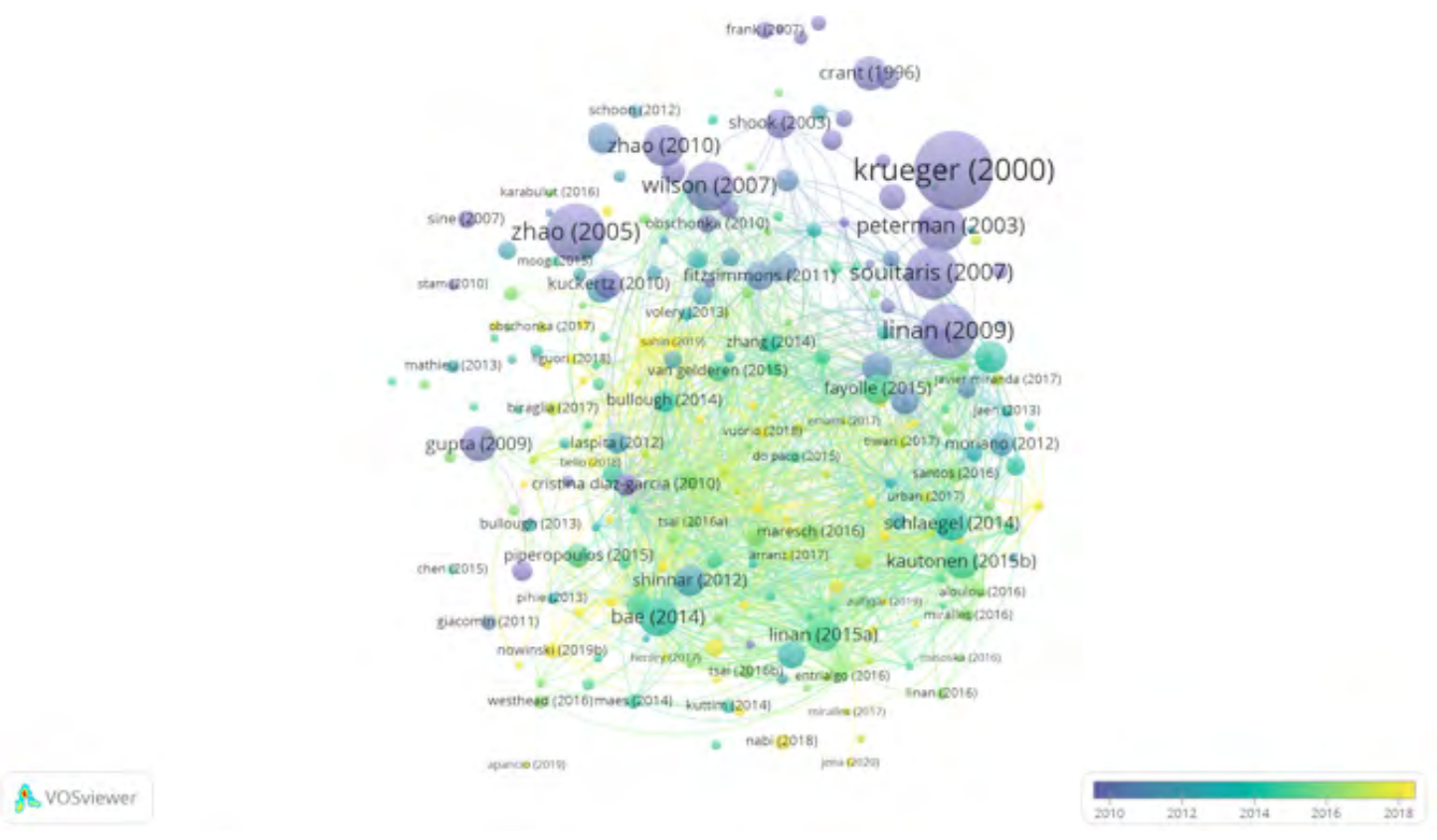

Figure 3

Bibliographic coupling papers in EI

Source: Own elaboration based on WoS using VOSviewer (Documents_bibliographic_coup_20).

\subsection{Journals}

The scientific communication process relies deeply on the revision, publication, and dissemination process that scientific journals perform. Table 3 shows the most productive journals in the EI academic field, including the Journal Citations Report Impact Factor for 2019 (IF19), the total number of papers published in EI, $\mathrm{H}$ index, and other statistics.

Table 3

Highly productive entrepreneurial intention scientific journals

\begin{tabular}{rlcrrrrrrrrr}
\hline $\mathbf{R}$ & J & IF19 & TPEI & \multicolumn{1}{c}{ H } & \multicolumn{1}{c}{ TC } & TP & TPEI/TP & $\geq \mathbf{1 0 0}$ & $\mathbf{2 5 0}$ & $\geq \mathbf{1 5}$ & $\mathbf{2 5}$ \\
\hline 1 & IEMJ & 3.472 & 50 & 24 & 2,254 & 589 & $8 \%$ & 6 & 4 & 16 & 18 \\
2 & EDTR & 1.791 & 43 & 23 & 2,699 & 449 & $10 \%$ & 0 & 0 & 7 & 15 \\
3 & STBY & 2.576 & 42 & 82 & 72,654 & 28,475 & $0 \%$ & 0 & 0 & 4 \\
4 & IJEBR & 3.529 & 37 & 27 & 3,780 & 365 & $10 \%$ & 0 & 1 & 13 & 8 \\
5 & FPSY & 2.067 & 26 & 118 & 105,968 & 19,406 & $0 \%$ & 0 & 0 & 3 & 6 \\
6 & JSBM & 3.461 & 25 & 101 & 41,723 & 1,074 & $2 \%$ & 5 & 6 & 7 \\
7 & JSBED & - & 22 & 21 & 2,233 & 325 & $7 \%$ & 0 & 0 & 7 \\
8 & ISJRE & 3.756 & 19 & 70 & 19,849 & 622 & $3 \%$ & 0 & 2 & 8 \\
9 & JGER & - & 19 & 10 & 517 & 136 & $14 \%$ & 0 & 0 & 1 \\
10 & SBEC & 4.803 & 19 & 123 & 77,609 & 2,117 & $1 \%$ & 4 & 4 & 7 \\
11 & JEEE & - & 17 & 13 & 816 & 165 & $10 \%$ & 0 & 0 & 2 \\
12 & SHED & 3 & 17 & 101 & 56,957 & 3,396 & $1 \%$ & 0 & 2 & 1 \\
13 & ETPR & 10.750 & 15 & 151 & 77,639 & 946 & $2 \%$ & 11 & 2 & 2 \\
14 & JOBR & 4.874 & 15 & 196 & 251,849 & 7,205 & $0 \%$ & 1 & 3 \\
15 & JAFEB & - & 14 & 17 & 4,118 & 1,006 & $1 \%$ & 0 & 0 \\
\hline
\end{tabular}

Source: Elaboration based on WoS and JCR.

Note: IF: Impact Factor; H: H-Index; TPEI: Total Publications Entrepreneurial Intention; TP: Total Publication; IEMJ: International Entrepreneurship and Management Journal; EDTR: Education And Training; STBY: Sustainability; IJEBR: International Journal of Entrepreneurial Behavior Research; FPSY: Frontiers In Psychology; JSBM: Journal of Small Business Management; JSBED: Journal of Small Business and Enterprise Development; ISJRE: International Small Business Journal Researching Entrepreneurship; JGER: Journal of Global Entrepreneurship Research; SBEC: Small Business Economics; JEEE: Journal Of Entrepreneurship In Emerging Economies; SHED: Studies In Higher Education; ETPR: Entrepreneurship Theory and Practice; JOBR: Journal of Business Research; JAFEB: Journal Of Asian Finance Economics and Business. Total is presented for TPEI, TC, TP, $\geq 100, \geq 50, \geq 15, \geq 5$ and is calculated as the sum of the top 15 Highly productive entrepreneurial intention scientific journals for each category. 
The top 15 journals sum a total of 380 papers published in EI. In general, these journals sum 66,276 papers published in other topics and areas of knowledge and a total of 720,665 citations. The most productive journal in EI is IEMJ, with 50 papers, followed by EDTR and STBY. The journal with the largest ratio of EI papers published over total papers is JGER with 14\%, followed by EDTR, IJEBR, and JEEE with $10 \%$ each. Finally, ETPR has eleven papers with more than 100 citations, followed by IEMJ with six and JSBM with five.

In bibliographic coupling journals (see Figure 4) is shown that some works published in them have had an interest in a common topic. This is highlighted international entrepreneurship journal, which is not included as a highly productive entrepreneurial intention scientific journal. It can also be seen that the most prominent journals (ETPR, SBEC) in EI publications appear in the graph as pioneering journals in the field of EI publication. STBY also stands out as a recent journal with an important presence in the field of EI. Thus, these results provide a fairly clear orientation of which journals are most relevant in EI and where current topics and possibilities to publish related work can be found.

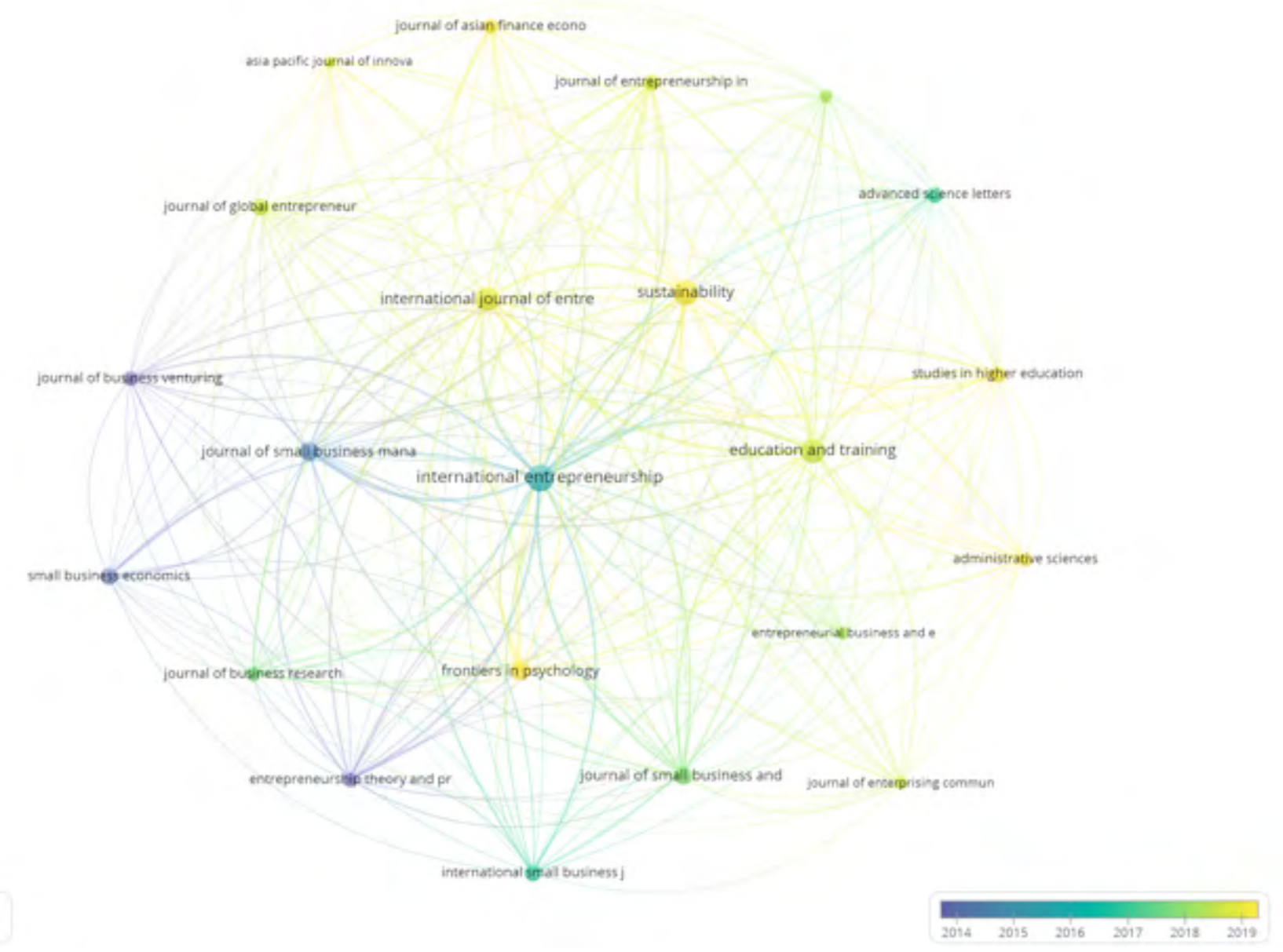

Figure 4

Bibliographic coupling journals in EI

Source: Own elaboration based on WoS using VOSviewer (Journals_bibliographic_coup_20).

\subsection{Authors}

Entrepreneurship intention is a fast-growing field of knowledge. The principal actors in the development of this area can be tracked in terms of productivity and influence. Table 4 shows the top 15 list of authors in EI, ranked by production. Some other statistics are also included, e.g., country of affiliation, $\mathrm{H}$ index, and production, in some of the most recognized journals in EI.

Liñan from Spain is the most productive author in EI; he is also the most cited author with 2,807 citations, with 140 cites per document published. In this list, Liñan is also the author who pub- lishes the most in highly productive EI journals; in total, he has published nine papers in the top 15 journals, five just in IEMJ. Liang is the second most productive author on the list with a total of 19 papers; in this case, this author has published two papers in the top 15 highly productive EI journals and sums a total of $178 \mathrm{ci}$ tations. Finally, Ip from Taiwan is the third most productive author with ten papers in EI. Please note that two more authors surpass 1,000 citations, Kautonen and Fayolle, respectively, with 1,096 and 1,082 citations. Therefore, these authors can be considered top influential in EI. Also, they have published eight papers in highly productive EI journals, 3 and 5 documents correspondingly. 
Table 4

Productive authors in entrepreneurial intention

\begin{tabular}{|c|c|c|c|c|c|c|c|c|c|c|c|c|c|c|c|c|}
\hline \multirow{2}{*}{$\mathbf{R}$} & \multirow{2}{*}{ A } & \multirow{2}{*}{ C } & \multirow{2}{*}{ TP } & \multirow{2}{*}{$\mathbf{H}$} & \multirow{2}{*}{ TC } & \multirow{2}{*}{ TC/TP } & \multicolumn{10}{|c|}{ Publication in TOP 15 journals } \\
\hline & & & & & & & IEMJ & EDTR & STBY & IJEBR & FPSY & JSBM & JSBED & ISJRE & JGER & SBEC \\
\hline 1 & Linan F & ESP & 20 & 16 & 2,807 & 140 & 5 & 0 & 0 & 1 & 0 & 1 & 0 & 2 & 0 & 0 \\
\hline 2 & Liang CY & TWN & 19 & 7 & 178 & 9 & 0 & 0 & 2 & 0 & 0 & 0 & 0 & 0 & 0 & 0 \\
\hline 3 & Ip CY & TWN & 10 & 5 & 90 & 9 & 0 & 0 & 0 & 0 & 0 & 0 & 0 & 0 & 0 & 0 \\
\hline 4 & Moriano JA & ESP & 10 & 7 & 416 & 42 & 2 & 0 & 0 & 0 & 0 & 0 & 0 & 1 & 0 & 0 \\
\hline 5 & Kautonen T & FIN & 9 & 9 & 1,096 & 122 & 0 & 0 & 0 & 0 & 0 & 0 & 0 & 1 & 0 & 2 \\
\hline 6 & Rodriguez-Ariza L & ESP & 9 & 5 & 64 & 7 & 3 & 0 & 0 & 0 & 0 & 0 & 0 & 0 & 0 & 0 \\
\hline 7 & Bagheri A & IRN & 8 & 4 & 76 & 10 & 0 & 0 & 0 & 0 & 0 & 0 & 0 & 0 & 0 & 0 \\
\hline 8 & Garcia-Rodriguez FJ & ESP & 8 & 5 & 93 & 12 & 2 & 0 & 2 & 0 & 0 & 0 & 0 & 0 & 0 & 0 \\
\hline 9 & Karimi S & IRN & 8 & 5 & 197 & 25 & 0 & 0 & 0 & 0 & 1 & 1 & 0 & 0 & 0 & 0 \\
\hline 10 & Farrukh M & $\mathrm{CHN}$ & 7 & 5 & 74 & 11 & 0 & 1 & 0 & 0 & 0 & 0 & 0 & 0 & 0 & 0 \\
\hline 11 & Fayolle A & FRA & 7 & 7 & 1,082 & 155 & 2 & 1 & 0 & 0 & 0 & 2 & 0 & 0 & 0 & 0 \\
\hline 12 & Kitsios F & GRC & 7 & 3 & 21 & 3 & 0 & 0 & 0 & 0 & 0 & 0 & 0 & 0 & 0 & 0 \\
\hline 13 & Liu HC & TWN & 7 & 5 & 88 & 13 & 0 & 0 & 0 & 0 & 0 & 0 & 0 & 0 & 0 & 0 \\
\hline 14 & Pihie Zal & MYS & 7 & 4 & 75 & 11 & 0 & 0 & 0 & 0 & 0 & 0 & 0 & 0 & 0 & 0 \\
\hline 15 & Shinnar RS & USA & 7 & 7 & 470 & 67 & 2 & 0 & 0 & 0 & 0 & 1 & 0 & 3 & 0 & 0 \\
\hline
\end{tabular}

Source: Elaboration based on WoS.

Note: A: Authors; C: Country; TP: Total Publications; H: H-Index; TC: Total Citation; IEMJ: International Entrepreneurship and Management Journal; EDTR: Education and Training; STBY: Sustainability; IJEBR: International Journal of Entrepreneurial Behavior Research; FPSY: Frontiers in Psychology; JSBM: Journal of Small Business Management; JSBED: Journal of Small Business and Enterprise Development; ISJRE: International Small Business Journal Researching Entrepreneurship; JGER: Journal of Global Entrepreneurship Research; SBEC: Small Business Economics.

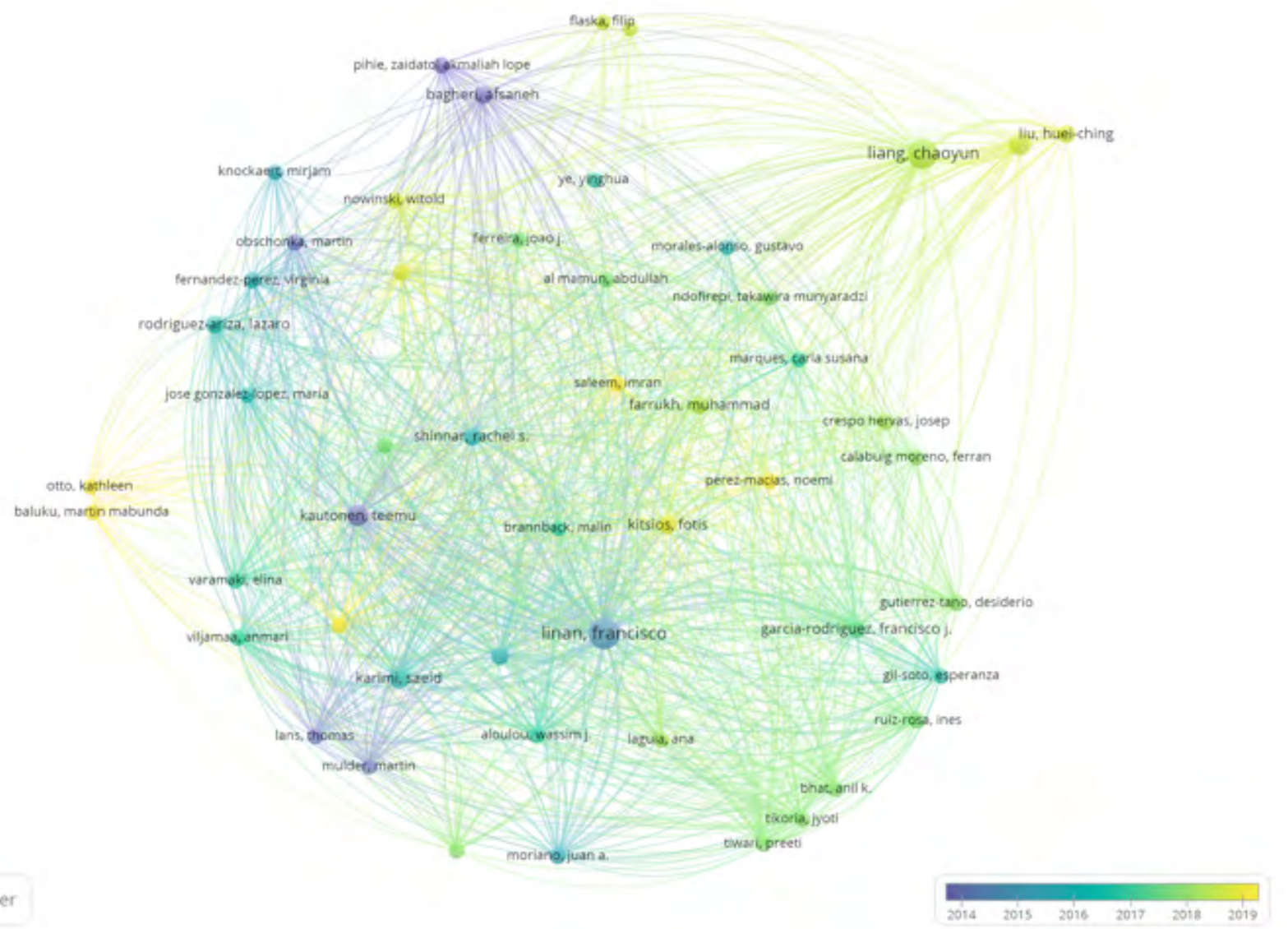

Figure 5

Authors coupling in EI

Source: Own elaboration based on WoS using VOSviewer (Authors_bibliographic_coup_5). 
In Figure 5, we can see the authors who have provided those common topics that guide the research. Among these, Liñán \& Fayolle (2015) stand out, who with his work " $A$ systematic literature review on entrepreneurial intentions: citation, thematic anal$y$ ses, and research agenda" has delimited those areas on which EI research focuses and the possible courses and lines that frame this field of research.

Also, several authors in Table 4 appear in this graph, indicating their relevance in EI research and their ideas have been sources for further contributions in this field.

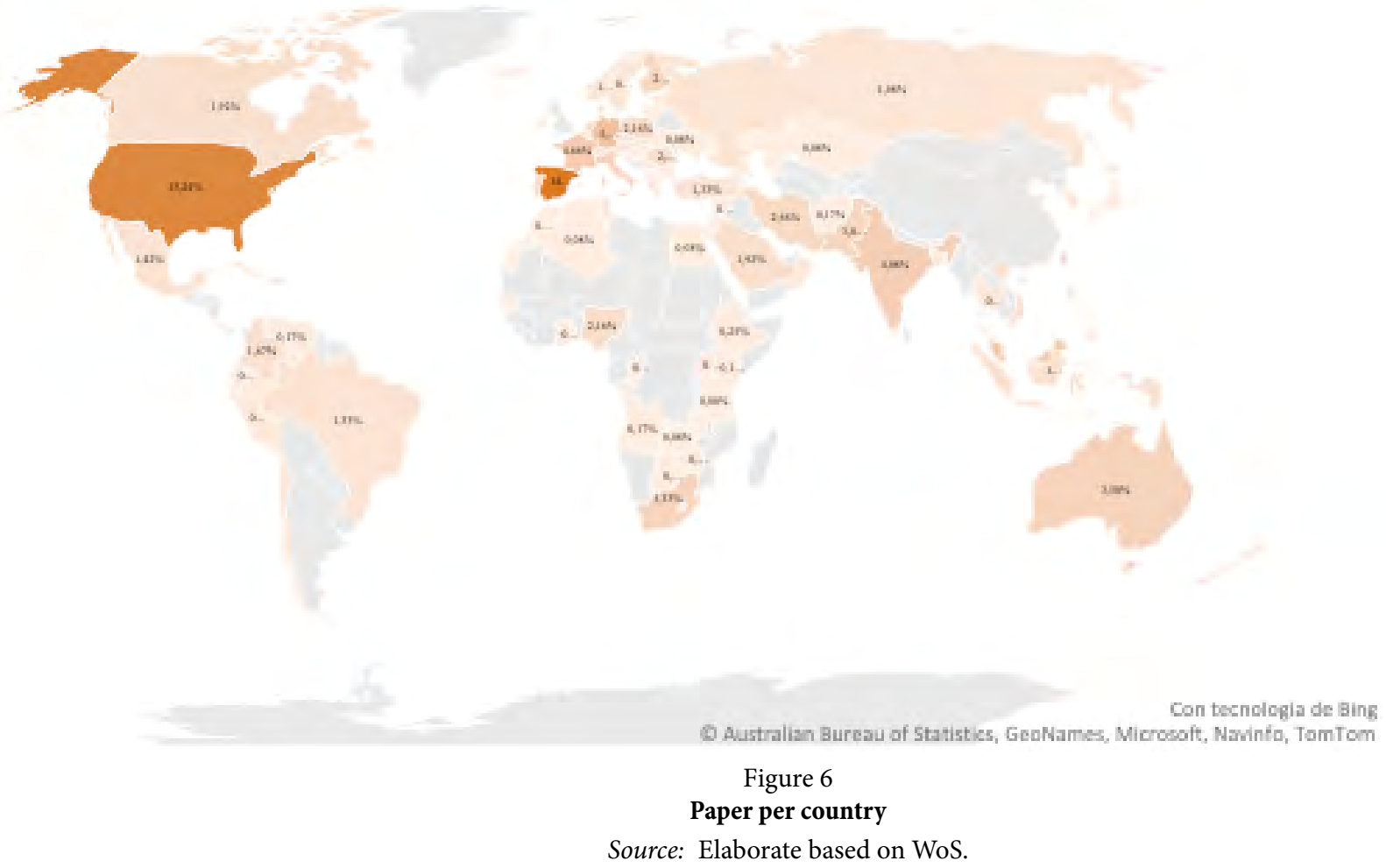

\subsection{Countries}

The number of papers per country is an interesting way to visualize how the topic is being studied abroad in the world (See Figure 6). With this information, it is possible to visualize how much a country is studying a topic and consider that it is possible to do more networking if you are a researcher or know where you can study if the topic is of interest when you are a student. For example, in the case of entrepreneurial intention, the countries with the most production are the USA and Spain (more than 10\% each), after that are Germany and France (with $6 \%$ and $5 \%$ respectively). On the other hand, in the case of Latin America is possible to see that many countries have papers but not with a high amount, such as the case of Colombia, Mexico, and Brazil.

\subsection{Universities}

Some organizations work as hubs for the generation of specific areas of knowledge. In the case of EI, the universities specializing in this area of knowledge can be observed by the number of publications generated by their staff. Table 5 shows the top 10 ranking of most productive organizations in EI scientific documents.
Table 5

Most productive universities in entrepreneurial intention

\begin{tabular}{rllccc}
\hline R & \multicolumn{1}{c}{ Organization } & Country & Publications & QS & Shanghai \\
\hline 1 & U Seville & ESP & 32 & $551-560$ & $401-500$ \\
2 & Natl Taiwan U & TWN & 23 & 69 & $201-300$ \\
3 & Alexandru Ioan Cuza U & ROU & 14 & $1001+$ & - \\
4 & U Beira Interior & PRT & 14 & - & - \\
5 & U Granada & ESP & 14 & $511-520$ & $201-300$ \\
6 & U Valencia & ESP & 13 & $581-590$ & $201-300$ \\
7 & Zhejiang U & CHN & 13 & 54 & 58 \\
8 & UNED & ESP & 12 & - & - \\
9 & U Tehran & IRN & 12 & $601-650$ & $301-400$ \\
10 & Erasmus U & NLD & 11 & 183 & 80 \\
\hline
\end{tabular}

Source: Elaboration based on WoS.

Note: U, University; UNED, Universidad Nacional de Educación a Distancia.

The University of Seville in Spain is the most productive organization in the ranking; it is followed by the National Taiwan University in Taiwan and Alexandru Ioan Cuza U in Romania. Please note that four organizations in the ranking are in Spain, concentrating on an interesting knowledge center in this region. From the ten universities displayed in the ranking, only three are 
not in Europe. Nonetheless, the organizations outside the European Union are well-known, recognized universities included in the top 100 QS ranking of world-leading universities. Another aspect that stands out is that 4 of the ten universities are Spanish. This indicates that research in IE is highly active in this country, which can influence and guide new lines and approaches in the field. They are also a reference point for postgraduate studies in this field.

\subsection{Keywords}

The co-occurrence analysis of the keywords (see Figure 7) shows the most frequently used terms that guide the topics studied. As Liñán and Fayolle (2015) had already mentioned in his work "A systematic literature review on entrepreneurial intentions: citation, thematic analyses, and research agenda," the works have focused on these identified lines, indicating the great influence they have had in organizing and determining the paths to follow in the EI research. In this sense, the topic related to education is quite relevant, where it focuses on the study of aspects related to higher education and university students from different areas of study and regions of the world (Apasieva et al., 2021; Cavalcante et al., 2021; Ferreira et al., 2017; Gabay-Mariani \& Boissin, 2021; Leiva et al., 2021; Lopez et al., 2021; Rueda Bar- rios et al., 2021; Torres et al., 2017). Some studies focus on the effectiveness of entrepreneurship education at different levels and ages. Already from the traits of individuals that allow examining behaviors towards entrepreneurial intention (Anjum et al., 2018; Huang \& Zhang, 2020), the mediating role of self-efficacy and attitude towards starting a new venture is further analyzed (Yousaf et al., 2020). Likewise, the motivational factors that influence EI continue to be studied (Solórzano-García et al., 2020). This is close to seminal studies such as planned behavior theory and the entrepreneurial event. Here, an interesting aspect is a breadth across regional and social spectrums where research is conducted (Mohammed et al., 2021), indicating a maturing process of understanding people's behavior towards entrepreneurship. A prominent topic is a relationship between Social Capital and EI, in which structures, languages, shared visions, networks, and ties can be observed (Pérez-Macías et al., 2020). Also, aspects include trust and commitment, desirability, perceived self-efficacy, and social norms (Ali \& Yousuf, 2019; Ha et al., 2020; Malebana, 2016). Another topical area of relevance in IE is related to social entrepreneurship (SE); in this approach, approaches are made to explain or model behavior towards SE using seminal variables used in this field, where approaches are made to explain or model behavior towards SE using seminal variables used in this field (Chien-Chi et al., 2020).

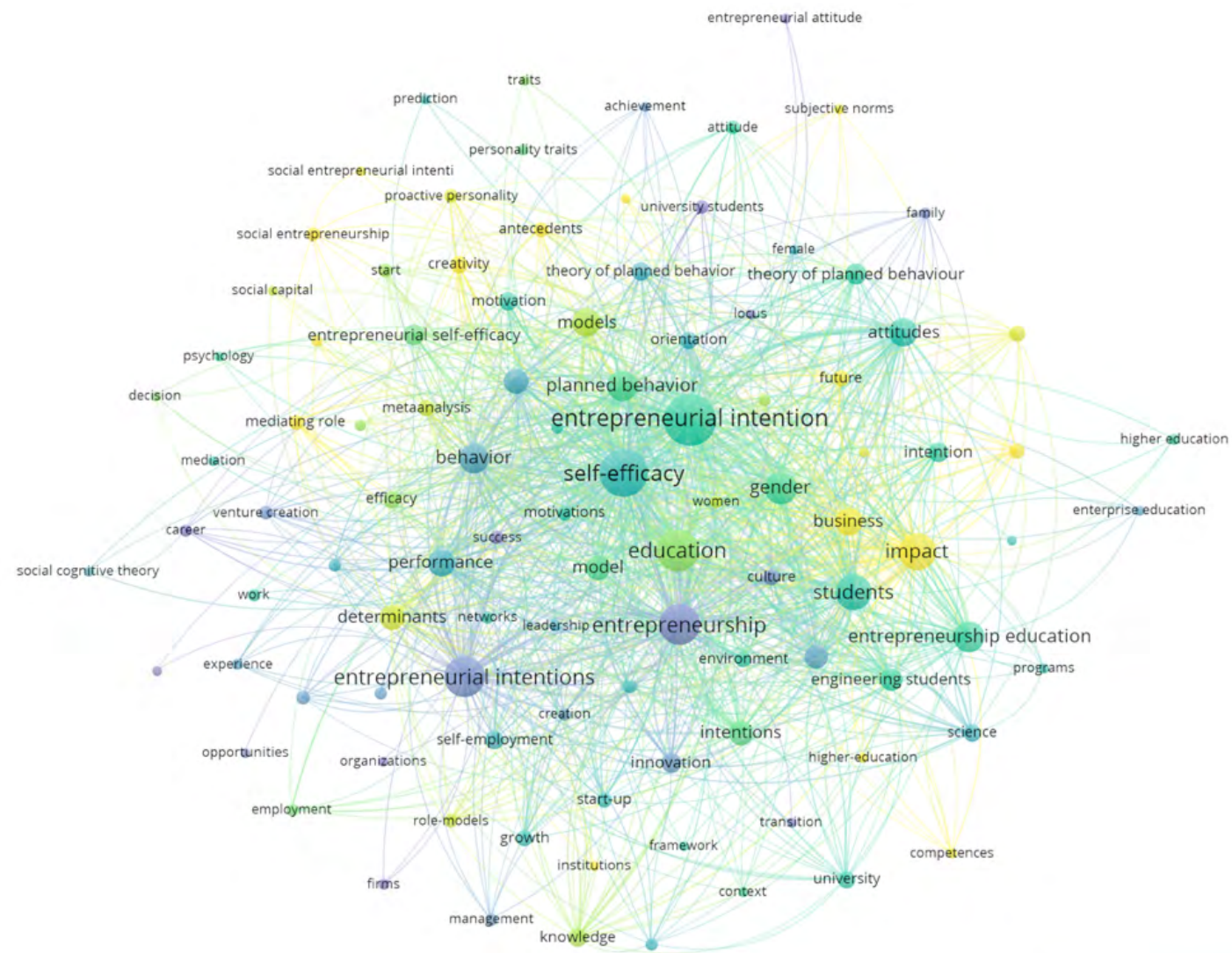


Thus, research on social entrepreneurial intention (Hockerts, 2017) has been developed considering empathy (Bacq \& Alt, 2018), emotional intelligence, creativity (Tiwari et al., 2017a), cognitive styles, self-efficacy (Tiwari et al., 2017b), and so on. Similarly, EI's studies have focused on specific regions that seek to understand or establish predictive aspects (Sousa-Filho et al., 2020). Furthermore, gender and EI studies have had a great development, and the other exposed topics, their studies are closely related in other contexts and populations. In addition, research has social, cultural (Anggadwita et al., 2021; Ilyas, 2020), academic (Di Paola, 2020; Gurel et al., 2021), and barrier (Patra \& Lenka, 2020) aspects. Finally, a recent topic of interest is decision making, which is associated with risk, uncertainty, and style factors that affect an individual's EI (Krasniqi et al., 2019; Ye, 2013; Zichella, 2020).

\section{DISCUSSION}

The entrepreneurial intention has been studied since 1991 when the first paper was published. Still, it was not until 2010 that the trend as a topic became more relevant, and in 2020 more than 300 papers have been written in journals indexed in the Web of Science. Moreover, the citation structure shows that most of the papers are not older than ten years, as shown in Table 1, where $66.5 \%$ of the papers have less than ten citations, which allows inferring that these papers are still in their initial stages and that there is still time to achieve greater relevance.

Some related studies on EI show interesting findings, e.g., Liñán and Fayolle (2015), centered their attention on articles published in the period of 2004 to 2013 , including the keywords "entrep ${ }^{*}$ " and "intent ${ }^{*}$ " the resulting amount of EI analyzed papers is 409 , concluding on EI as a consolidated area of research and six main lines of specialization within the studied papers, core entrepreneurial models, personal-level variables, entrepreneurship education, context and institutions, entrepreneurial process and new research areas. Tan et al. (2019) perform a systematic literature review on social EI, using Liñán and Fayolle (2015) keywords and adding the keyword "social," the period for the search is limited to 2019. After a thorough selection process, the authors identify 36 papers addressing social EI. The results show rapid attention to the topic since 2010 and define the role of pro-social personality traits as potential lines of research given the social component of the addressed review, also relevant topics to consider in future developments as the expectancy theory, the social cognitive career theory, prospect theory and effectuation theory (please see Tan et al. (2019)). Neves and Brito (2020) perform a systematic review of the networking academicians' EI papers published from 2007-2018 using the same keywords as in Liñán and Fayolle (2015) and combining them with academ ${ }^{\star}$, universit*, intention, attitude, behavior, motivation, and engagement, among others. The result yields 66 papers and concludes with clusters of variables that affect academicians' entrepreneurial intention and knowledge valorization activities pinpointing cultural factors as critical for further developments.

Based on the number of citations to rank the most important papers, five papers are from $2014-2015$, and $36 \%$ of the total cita- tions are in the top 3 papers. Interestingly, 8 of the 15 papers were published in Entrepreneurship Theory and Practice, making this journal one of the most important in the field based on Table 2 . Also, if we consider the number of papers published in each journal, the most relevant one is the International Entrepreneurship and Management Journal; based on their citations, it is the Journal of Business Research. Therefore, as has been told, based on citations, Entrepreneurship Theory and Practice are the most important. This idea is very interesting because the journal with more papers will not always have the most cited papers.

An important thing to analyze in the bibliometric studies is based on the authors published in a specific field. It is noteworthy that 4 of the 15 authors are from Spain. Another country that has three productive authors in entrepreneurial intention is Taiwan. This can be confirmed with Table 5 where it shows that the most productive universities are the University of Seville (Spain) and National Taiwan University (Taiwan).

\section{CONCLUSION}

This paper presents a bibliometric approach of the literature on entrepreneurial intention based on the Web of Science database. The main motivation was to analyze the evolution of this field and understand what has been happening based on the publication's perspective. Among the most important data obtained are that 1549 papers have been published from 1996 to December 2020 using the keywords "Entrepreneurial intention $^{\star}$ " OR "Entrepreneur* AND intention ${ }^{\star}$ " in the Core Collection of the WoS.

Among the main results that were possible to visualize is that entrepreneurial intention is a field that started to gain recognition or popularity in 2010. Because of this, not many papers have more than ten citations, but this does not mean that they are not important, is that compared with other fields that have more history, this is a recent field. Another interesting thing is that one of the most important journals based on the citations of their papers is Entrepreneurship Theory and Practice, even when it is number 13 based on the number of papers. Finally, two important countries with authors and the most productive universities in the field are Spain and Taiwan.

Although the paper presents an interesting overview of entrepreneurial intention, it presents several limitations based on the methodology used to make it. Among the most important limitations is that only the Core Collection of the Web of Science was used, leaving papers published in journals indexed in other databases. Because of that, maybe some important papers are not presented in the study.

Since the first reviews, culture, education, personality traits, and gender have been highlighted as relevant topics of study as axes of deepening research in IE. In addition, the findings found new research paths focused on pro-social personal traits. On the one hand, social capital and social entrepreneurship are noteworthy to social approach across regional and social spectrums. On the other hand, empathy, emotional intelligence, creativity, and decision-making are noteworthy to personal traits. These themes can expand the theoretical approaches and explanations for practitioners on how to approach IE in more specific contexts. 


\section{ACKNOWLEDGMENT}

This research was funded by Universidad Pedagogica y Tecnologica de Colombia, grant number SGI 3134, and the Chilean Government through FONDECYT initiation, grant number 11190056. Research supported by Red Sistemas Inteligentes y Expertos Modelos Computacionales Iberoamericanos (SIEM$\mathrm{CI}$ ), project number 522RT0130 in Programa Iberoamericano de Ciencia y Tecnologia para el Desarrollo (CYTED)

\section{REFERENCES}

Ajzen, I. (1991). The theory of planned behavior. Organizational Behavior and Human Decision Processes, 50(2), 179-211. https://doi. org/10.1016/0749-5978(91)90020-T

Ali, A., \& Yousuf, S. (2019). Social capital and entrepreneurial intention: Empirical evidence from rural community of Pakistan. Journal of Global Entrepreneurship Research, 9(1), 1-13. https://doi. org/10.1186/s40497-019-0193-Z

Alonso, S., Cabrerizo, F. J., Herrera-Viedma, E., \& Herrera, F. (2009). h-Index: A review focused in its variants, computation and standardization for different scientific fields. Journal of Informetrics, 3(4), 273-289. https://doi.org/10.1016/j.joi.2009.04.001

Anggadwita, G., Ramadani, V., Permatasari, A., \& Alamanda, D. T. (2021). Key determinants of women's entrepreneurial intentions in encouraging social empowerment. Service Business, 15(2), 309-334. https://doi.org/10.1007/s11628-021-00444-x

Anjum, T., Sharifi, S., Nazar, N., Farrukh, M., \& Candidates, P. (2018). Determinants of entrepreneurial intention in perspective of theory of planned behaviour. Management Theory and Studies for Rural Business and Infrastructure Development, 40(4), 429-441. https:// doi.org/10.15544/mts.2018.40

Apasieva, T. J., Rajh, E., Budak, J., \& Davčev, L. (2021). Entrepreneurial intentions of students at private universities in transition economies. Ekonomski pregled, 72(2), 157-184. https://doi.org/10.32910/ep.72.2.1

Bacq, S., \& Alt, E. (2018). Feeling capable and valued: A prosocial perspective on the link between empathy and social entrepreneurial intentions. Journal of Business Venturing, 33(3), 333-350. https://doi. org/10.1016/j.jbusvent.2018.01.004

Bae, T. J., Qian, S., Miao, C., \& Fiet, J. O. (2014). The relationship between entrepreneurship education and entrepreneurial intentions: A meta-analytic review. Entrepreneurship: Theory and Practice, 38(2), 217-254. https://doi.org/10.1111/etap.12095

Bar-Ilan, J. (2008). Informetrics at the beginning of the 21st century-A review. Journal of Informetrics, 2(1), 1-52. https://doi.org/10.1016/J. JOI.2007.11.001

Blanco-Mesa et al. (2019). A bibliometric analysis of aggregation operators. Applied Soft Computing, 81, 105488. https://doi.org/10.1016/J. ASOC.2019.105488

Blanco-Mesa, F., Merigó, J. M., \& Gil-Lafuente, A. M. (2017). Fuzzy decision making: A bibliometric-based review. Journal of Intelligent \& Fuzzy Systems, 32(3), 2033-2050. https://doi.org/10.3233/JIFS-161640

Braun, T., Glänzel, W., \& Schubert, A. (2006). A Hirsch-type index for journals. Scientometrics, 69(1), 169-173. https://doi.org/10.1007/s11192006-0147-4

Bruton, G. D., Ahlstrom, D., \& Li, H.-L. (2010). Institutional theory and entrepreneurship: Where are we now and where do we need to move in the future? Entrepreneurship Theory and Practice, 34(3), 421-440. https://doi.org/10.1111/j.1540-6520.2010.00390.x

Cai, L., Murad, M., Ashraf, S. F., \& Naz, S. (2021). Impact of dark tetrad personality traits on nascent entrepreneurial behavior: The media- ting role of entrepreneurial intention. Frontiers of Business Research in China, 15(1), 7. https://doi.org/10.1186/s11782-021-00103-y

Cavalcante, M. A. D., Sousa-Filho, J. M. de, \& Lessa, B. de S. (2021). Entrepreneurial intentions and education: Effects on low-income students. Journal of Education for Business, 1-9. https://doi.org/10. 1080/08832323.2021.1924602

Chien-Chi, C., Sun, B., Yang, H., Zheng, M., \& Li, B. (2020). Emotional competence, entrepreneurial self-efficacy, and entrepreneurial intention: A study based on China College students' social entrepreneurship project. Frontiers in Psychology, 11, 2883. https://doi. org/10.3389/fpsyg.2020.547627

Di Paola, N. (2020). Pathways to academic entrepreneurship: The determinants of female scholars' entrepreneurial intentions. Journal of Technology Transfer, 1-25. https://doi.org/10.1007/s10961-020-09824-3

Díaz-García, M. C., \& Jiménez-Moreno, J. (2010). Entrepreneurial intention: The role of gender. International Entrepreneurship and $\mathrm{Ma}$ nagement Journal, 6(3), 261-283. https://doi.org/10.1007/s11365008-0103-2

DiMaggio, P. (1988). Interest and agency in institutional theory. En L. Zucker (Ed.), Institutional patterns and organizations: Culture and environment (pp. 3-21). Ballinger Publishing.

Farhangmehr, M., Gonçalves, P., \& Sarmento, M. (2016). Predicting entrepreneurial motivation among university students. Education + Training, 58(7/8), 861-881. https://doi.org/10.1108/ET-01-2016-0019

Fayolle, A., \& Gailly, B. (2015). The impact of entrepreneurship education on entrepreneurial attitudes and intention: Hysteresis and persistence. Journal of Small Business Management, 53(1), 75-93. https://doi.org/10.1111/jsbm.12065

Fayolle, A., \& Liñán, F. (2014). The future of research on entrepreneurial intentions. Journal of Business Research, 67(5), 663-666. https://doi. org/10.1016/j.jbusres.2013.11.024

Ferreira, J. J., Fernandes, C. I., \& Ratten, V. (2017). The Influence of Entrepreneurship Education on Entrepreneurial Intentions (pp. 19-34). Springer, Cham. https://doi.org/10.1007/978-3-319-47949-1_2

Gabay-Mariani, L., \& Boissin, J.-P. (2021). Commitment profiles of nascent entrepreneurs: Insights from an empirical taxonomy among French student entrepreneurs. International Journal of Entrepreneurial Behavior \& Research, ahead-of-print(ahead-of-print). https:// doi.org/10.1108/IJEBR-09-2020-0652

Garfield, E. (1972). Citation analysis as a tool in journal evaluation. Science, 178(4060), 471-479.

Gaviria-Marín, M. (2021). Bibliometrics and business. A challenge for researchers. INQUIETUD EMPRESARIAL, 21(1), I-III.

Guan, J., \& Gao, X. (2008). Comparison and evaluation of Chinese research performance in the field of bioinformatics. Scientometrics, 75(2), 357-379. https://doi.org/10.1007/s11192-007-1871-0

Gupta, V. K., Turban, D. B., Wasti, S. A., \& Sikdar, A. (2009). The role of gender stereotypes in perceptions of entrepreneurs and intentions to become an entrepreneur. Entrepreneurship: Theory and Practice, 33(2), 397-417. https://doi.org/10.1111/j.1540-6520.2009.00296.x

Gurel, E., Madanoglu, M., \& Altinay, L. (2021). Gender, risk-taking and entrepreneurial intentions: Assessing the impact of higher education longitudinally. Education + Training, 63(5), 777-792. https:// doi.org/10.1108/et-08-2019-0190

Ha, N. T., Doan, X. H., Vu, T. N., Linh Nguyen, T. P., Phan, T. H., \& Duong, C. D. (2020). The effect of social capital on social entrepreneurial intention among vietnamese students. Journal of Asian Finance, Economics and Business, 7(8), 671-680. https://doi. org/10.13106/JAFEB.2020.VOL7.NO8.671

Hirsch, J. E. (2005). An index to quantify an individual's scientific research output. Proceedings of the National Academy of Sciences of the United States of America, 102(46), 16569-16572. https://doi. org/10.1073/pnas.0507655102 
Hockerts, K. (2017). Determinants of social entrepreneurial intentions. Entrepreneurship: Theory and Practice, 41(1), 105-130. https://doi. org/10.1111/etap.12171

Huang, Y., \& Zhang, J. (2020). Social media use and entrepreneurial intention: The mediating role of self-efficacy. Social Behavior and Personality, 48(11). https://doi.org/10.2224/sbp.9451

Ilyas, M. (2020). Gender role stereotyping and entrepreneurial intention among Saudi females. International Transaction Journal of Engineering Management \& Applied Sciences \& Technologies, 11(9), 11A9E.

Kautonen, T., Tornikoski, E. T., \& Kibler, E. (2011). Entrepreneurial intentions in the third age: The impact of perceived age norms. Small Business Economics, 37(2), 219-234. https://doi.org/10.1007/ s11187-009-9238-y

Krasniqi, B. A., Berisha, G., \& Pula, J. S. (2019). Does decision-making style predict managers' entrepreneurial intentions? Journal of Global Entrepreneurship Research, 9(1), 1-15. https://doi.org/10.1186/ s40497-019-0200-4

Krueger, N. F., Reilly, M. D., \& Carsrud, A. L. (2000). Competing models of entrepreneurial intentions. Journal of Business Venturing, 15(5-6), 411-432. https://doi.org/10.1016/S0883-9026(98)00033-0

Leiva, J. C., Mora-Esquivel, R., Krauss-Delorme, C., Bonomo-Odizzio, A., \& Solís-Salazar, M. (2021). Entrepreneurial intention among Latin American university students. Academia Revista Latinoamericana de Administración, ahead-of-p(ahead-of-print). https://doi. org/10.1108/ARLA-05-2020-0106

Liñán, F., \& Chen, Y. W. (2009). Development and cross-cultural application of a specific instrument to measure entrepreneurial intentions. Entrepreneurship Theory and Practice, 33(3), 593-617.

Liñán, F., \& Fayolle, A. (2015). A systematic literature review on entrepreneurial intentions: Citation, thematic analyses, and research agenda. International Entrepreneurship and Management Journal, 11(4), 907-933. https://doi.org/10.1007/s11365-015-0356-5

Liu, W. (2019). The data source of this study is Web of Science Core Collection? Not enough. Scientometrics 2019 121:3, 121(3), 1815-1824. https://doi.org/10.1007/S11192-019-03238-1

Lopez, T., Alvarez, C., Martins, I., Perez, J. P., \& Románn-Calderón, J. P. (2021). Students' perception of learning from entrepreneurship education programs and entrepreneurial intention in Latin America. Academia Revista Latinoamericana de Administración, ahead-ofp(ahead-of-print). https://doi.org/10.1108/arla-07-2020-0169

López-Núñez, M. I., Rubio-Valdehita, S., Díaz-Ramiro, E., \& Martín-Seoane, G. (2021). The entrepreneurial profile of university students: A predictive model. Revista de Educación, 392, 11-33. https:// doi.org/10.4438/1988-592X-RE-2021-392-477

Malebana, M. J. (2016). The infl uencing role of social capital in the formation of entrepreneurial intention. Southern African Business Review, 20, 51-70.

Merigo, J. M., Blanco-Mesa, F., Gil-Lafuente, A. M., \& Yager, R. R. (2017). Thirty years of the International Journal of Intelligent Systems: A bibliometric review. International Journal of Intelligent Systems, 32(5), 526-554.

Moed, H. F. (2009). New developments in the use of citation analysis in research evaluation. Archivum immunologiae et therapiae experimentalis, 57(1), 13-18. https://doi.org/10.1007/s00005-0090001-5

Mohammed, S. A. S. A., Qataan, A. M. Al, Ghawanmeh, F., \& Alqaadan, F. (2021). Personality traits, self-efficacy, and students' entrepreneurial intention towards entrepreneurship-Is there a contextual difference. SMART Journal of Business Management Studies, 17(1), 66-79. https://doi.org/10.5958/2321-2012.2021.00007.5

Neves, S., \& Brito, C. (2020). Academic entrepreneurship intentions: A systematic literature review. Journal of Management Development, 39(5), 645-704. https://doi.org/10.1108/JMD-11-2019-0451
Patra, B. C., \& Lenka, U. (2020). Barriers to entrepreneurial intentions of women: Nominal group technique, analytic hierarchy process, and scientometric approach instigating the necessity of policy intervention. Journal of Public Affairs, e2429. https://doi.org/10.1002/pa.2429

Pérez-Macías, N., Fernández-Fernández, J. L., \& Rúa-Vieites, A. (2020). Entrepreneurial intention among online and face-to-face university students: The influence of structural and cognitive social capital dimensions. Journal of International Entrepreneurship, 1-34. https:// doi.org/10.1007/s10843-020-00280-6

Peterman, N. E., \& Kennedy, J. (2003). Enterprise Education: Influencing Students' Perceptions of Entrepreneurship. Entrepreneurship Theory and Practice, 28(2), 129-144. https://doi.org/10.1046/j.15406520.2003.00035.x

Phillips, N., \& Tracey, P. (2016). Opportunity recognition, entrepreneurial capabilities and bricolage: Connecting institutional theory and entrepreneurship in strategic organization: http:// dx.doi.org/10.1177/1476127007079956, 5(3), 313-320. https://doi. org/10.1177/1476127007079956

Romero, M. E. P., Flores-Romero, M. B., Alfaro-García, V. G., \& Merigó, J. M. (2021). Tourism competitiveness: Bibliometric analysis of global scientific production from 1991 to 2018. Inquietud Empresarial, 21(1), 55-73. https://doi.org/10.19053/01211048.11476

Rueda Barrios, G. E., Rodriguez, J. F. R., Plaza, A. V., Vélez Zapata, C. P., \& Zuluaga, M. E. G. (2021). Entrepreneurial intentions of university students in Colombia: Exploration based on the theory of planned behavior. Journal of Education for Business, 1-10. https://doi.org/10. 1080/08832323.2021.1918615

Ruiz-Alba, J. L., Guzman-Parra, V. F., Oblitas, J. R. V., \& Mediano, J. M. (2020). Entrepreneurial intentions: A bibliometric analysis. Journal of Small Business and Enterprise Development.

Schlaegel, C., \& Koenig, M. (2014). Determinants of entrepreneurial intent: A meta-analytic test and integration of competing models. Entrepreneurship: Theory and Practice, 38(2), 291-332. https://doi. org/10.1111/etap.12087

Schubert, A. (2007). Successive h-indices. Scientometrics, 70(1), 201205. https://doi.org/10.1007/s11192-007-0112-x

Shane, S. (2003). A general theory of entrepreneurship: The individual-opportunity nexus. E. Elgar.

Shane, S., \& Venkataraman, S. (2000). The promise of entrepreneurship as a field of research. Academy of management review, 25(1), 217-226.

Shapero, A. (1984). The entrepreneurial event. ollege of Administrative Science, Ohio State University.

Shinnar, R. S., Giacomin, O., \& Janssen, F. (2012). Entrepreneurial perceptions and intentions: The role of gender and culture. Entrepreneurship: Theory and Practice, 36(3), 465-493. https://doi.or$\mathrm{g} / 10.1111 / \mathrm{j} .1540-6520.2012 .00509 . \mathrm{x}$

Solórzano-García, M., Navio-Marco, J., \& Laguia, A. (2020). The influence of intrinsic motivation and contextual factors on MOOC students' social entrepreneurial intentions. En Interactive Learning Environments. Routledge. https://doi.org/10.1080/10494820.2020.1769680

Souitaris, V., Zerbinati, S., \& Al-Laham, A. (2007). Do entrepreneurship programmes raise entrepreneurial intention of science and engineering students? The effect of learning, inspiration and resources. Journal of Business Venturing, 22(4), 566-591. https://doi. org/10.1016/j.jbusvent.2006.05.002

Sousa-Filho, J. M. de, Matos, S., da Silva Trajano, S., \& de Souza Lessa, B. (2020). Determinants of social entrepreneurial intentions in a developing country context. Journal of Business Venturing Insights, 14, e00207. https://doi.org/10.1016/j.jbvi.2020.e00207

Tan, L. P., Le, A. N. H., \& Xuan, L. P. (2019). A systematic literature review on social entrepreneurial intention. https://doi.org/10.1080/ 19420676.2019.1640770, 11(3), 241-256. https://doi.org/10.1080/19 420676.2019 .1640770 
Tiwari, P., Bhat, A. K., \& Tikoria, J. (2017a). Predictors of social entrepreneurial intention: An empirical study. South Asian Journal of Business Studies, 6(1), 53-79. https://doi.org/10.1108/SAJBS-04-2016-0032

Tiwari, P., Bhat, A. K., \& Tikoria, J. (2017b). An empirical analysis of the factors affecting social entrepreneurial intentions. Journal of Global Entrepreneurship Research, 7(1), 1-25. https://doi.org/10.1186/ s40497-017-0067-1

Torres, F. C., Méndez, J. C. E., Barreto, K. S., Chavarría, A. P., Machuca, K. J., \& Guerrero, J. A. O. (2017). Exploring entrepreneurial intentions in Latin American university students. International Journal of Psychological Research, 10(2), 46-59. https://doi. org/10.21500/20112084.2794

Tremblay, M., \& Gasse, Y. (2011). Entrepreneurial beliefs and intentions: A cross-cultural study of university students in seven countries. International Journal of Business, 16(4), 303-314.

Weinberg, B. H. (1974). Bibliographic coupling: A review. Information Storage and Retrieval, 10(5-6), 189-196. https://doi. org/10.1016/0020-0271(74)90058-8

Wilson, F., Kickul, J., \& Marlino, D. (2007). Gender, entrepreneurial self-efficacy, and entrepreneurial career intentions: Implications for entrepreneurship education. Entrepreneurship: Theory and Practice, 31(3), 387-406. https://doi.org/10.1111/j.15406520.2007.00179.x

Ye, Y. (2013). The effect of temporal distance on Chinese undergraduates' entrepreneurial decision making. Social Behavior and Personality, 41(7), 1125-1132. https://doi.org/10.2224/sbp.2013.41.7.1125

Yousaf, U., Ali, S. A., Ahmed, M., Usman, B., \& Sameer, I. (2020). From entrepreneurial education to entrepreneurial intention: A sequential mediation of self-efficacy and entrepreneurial attitude. International Journal of Innovation Science, 13(3), 364-380. https://doi. org/10.1108/IJIS-09-2020-0133

Zhao, H., Hills, G. E., \& Seibert, S. E. (2005). The mediating role of self-efficacy in the development of entrepreneurial intentions. Journal of Applied Psychology, 90(6), 1265-1272. https://doi. org/10.1037/0021-9010.90.6.1265

Zhao, H., Seibert, S. E., \& Lumpkin, G. T. (2010). The relationship of personality to entrepreneurial intentions and performance: A meta-analytic review. Journal of Management, 36(2), 381-404. https:// doi.org/10.1177/0149206309335187

Zichella, G. (2020). Surprisingly stable: An experiment on willingness to bear uncertainty in individuals with and without entrepreneurial intentions. Journal of Management Development, 39(9-10), 9891011. https://doi.org/10.1108/JMD-01-2019-0013 
